\title{
JAPAN'S NATIONAL IDENTITY, TERRITORIAL DISPUTES AND SUB-STATE ACTORS: NORTHERN TERRITORIES/SOUTH KURILES AND TAKESHIMA/DOKDO COMPARED ${ }^{1}$
}

\author{
Alexander Bukh ${ }^{2}$ \\ Victoria University of Wellington
}

\begin{abstract}
:
This paper joins the constructivist debate on Japan's national identity and foreign policy. Mainstream constructivists that look at norms as main components of national identity have focused on Japan's anti-militarist or pacifist identity. While paying attention to the process of the emergence and institutionalisation of the anti-militarist norms their works have implied the existence of certain coherence between the intentions of the various actors that participated in this process and the final institutionalised norm. On the other hand, critical constructivists that construe identity of the national "self" as constructed in opposition to the difference of multiple "others" have focused on broad identity discourses and have paid little attention to the role of concrete issues and events in the continuous reproduction of these discourses as well as the processes through which these identity discourses emerge. This talk is guided by the critical constructivist ontology. It will focus however on the processes that led to the emergence of two territorial disputes, Northern Territories and Takeshima, as main building blocs in the discursive construction of Japan's postwar identity vis-a-vis Russia and South Korea respectively. It examines the role of sub-state actors such as municipalities and civil society groups in these processes. I will argue that while both of the final constructs are quite similar, the processes that led to their emergence have some very important differences. Furthermore, by analysing the interests of these actors the paper argues that their interests had little in common with the final identity constructs. This argument questions the ideational coherence of the process of national identity construction implied in mainstream constructivist works.
\end{abstract}

Keywords: Japan, Takeshima, Northern Territories, Constructivism, Non-State Actors.

\section{Resumen:}

Este artículo se une al debate del constructivismo en torno a la identidad nacional de Japón y a su política exterior. El constructivismo de corte convencional que examina el marco normativo como el principal componente de la identidad nacional se ha centrado en su identidad pacifista y en su explícito antimilitarismo. Al mismo tiempo que se prestaba atención al proceso de emergencia e institucionalización de las normas antimilitaristas, sus obras han dado por sentada la existencia de una cierta coherencia entre las intenciones de los varios actores que formaban parte del proceso de institucionalización. Por otra parte, constructivistas de la escuela crítica que observan la construcción de la identidad nacional como un proceso en el que el "yo" se contrapone a una serie múltiple de "otros", se han centrado de forma amplia en discursos identitarios y no han prestado atención al papel de asuntos y sucesos concretos en la reproducción de esos mismos discursos y en los procesos a través de los cuáles tal discurso identitario emerge. En esta discusión, nos guiaremos por la ontología del constructivismo crítico. Sin embargo, nos fijaremos igualmente en los procesos por los que emergieron dos disputas territoriales, la de los Territorios del Norte y las islas Takeshima, como bloques discursivos en la construcción de la identidad del Japón de posguerra frente a Rusia y a Corea del Sur respectivamente. El artículo examina el papel de actores sub-estatales tales como las administraciones municipales y agrupaciones civiles en tales procesos. Argumentaré que si bien los constructos finales de ambos procesos acaban siendo similares, los procesos que llevaron a su emergencia contienen importantes diferencias. Además, analizando los intereses de estos actores, este artículo explica cómo sus intereses tenían poco que ver con el constructo final que acabó emergiendo. El argumento principal del artículo por tanto pone en duda la coherencia del proceso de identidad nacional que se presupone en las obras del constructivismo convencional.

Palabras clave: Japón, Takeshima, Territorios del Norte, constructivismo, actores no estatales.

Copyright $($ ) UNISCI, 2013.

Las opiniones expresadas en estos artículos son propias de sus autores, y no reflejan necesariamente la opinión de UNISCI. The views expressed in these articles are those of the authors, and do not necessarily reflect the views of UNISCI.

\footnotetext{
${ }^{1}$ Research conducted for this article was partially funded by the Academy of Korean Studies Grant (AKS-2011R56).

${ }^{2}$ Alexander Bukh is senior lecturer at the School of History, Philosophy, Political Science \& International Relations of the Victoria University of Wellington.

E-mail: alexander.bukh@vuw.ac.nz.
}

http://dx.doi.org/10.5209/rev_UNIS.2013.n32.4479[ 


\section{Introduction}

This paper joins the debate on the construction of Japan's national identity. The theoretical premises that guide paper are located within the "critical" branch of IR constructivism. Unlike the liberal branch of constructivist theory that focuses on social structures constituted by norms and ideas, critical constructivism emphasizes the role of difference attributed to the "other" and meanings associated with this difference, as a key element in the construction of the (national) "self". 3 Following these ontological premises, most of the empirical works associated with the critical constructivist school focus on broad identity discourses in which the national "self" is hierarchically juxtaposed with its significant "others" through broad historical narratives, depictions of cultural attributes of the "other" and normative analyses of the "other's" political structures and institutions.

Arguably however, these broad discourses rely on very specific events and issues for legitimization of the various meanings embedded in them and even more importantly when competing with other discourses for dominance. Thus few would dispute the argument that Stalin's purges or China's Communist Party's internet censorship have played an important role in the construction of US identity vis-à-vis the Soviet Union and today's China respectively. Focusing on the broad discourses, however, quite often critical constructivist scholarship tends to ignore the processes through which certain issues and events are incorporated into various identity discourses. In some cases, like the examples above, the answers may be quite obvious and not requiring further academic scrutiny. In other cases however, including the territorial disputes discussed below, the actual process of incorporation of a specific event or issue into national identity discourse is more complex than it may seem. This paper seeks to address this question by analyzing the role of the various sub-state actors in bringing the territorial disputes to the fore of national identity discourses, their interests and interactions with other actors.

The centrality of territorial disputes in national identity constructs seems to be rather obvious. Territory is one of the main attributes of a nation and thus any instance of its contestation can be expected to play an important if not central role in the discursive construction of the national "self". Furthermore, the process of the "self" identity construction involves complex instances of ideational differentiation between the self and the outside. On the other hand, borders, as sharply drawn territorial lines, by definition, create a geographical distinction between the "self" and the outside. As such, it can be argued, issues that relate to the geographical delimitation of the national "self" are potent tools in the process of ideational construction of borders that distinguish the "self" from its "others".

This paper focuses on two territorial disputes that involve postwar Japan: the Northern Territories/ South Kuriles dispute with USSR/Russia and the Takeshima/Dokdodispute with South Korea. As this article focuses solely on Japan, purely for the sake of convenience the Japanese names for the disputed territories (Northern Territories and Takeshima) will be used throughout the main body of the paper. The historical background of the disputes and the historical arguments forwarded by Japan and the other parties to support their respective claims have been thoroughly discussed and analyzed by other scholars. Some of them are mentioned in other articles in this issue. Thus for lack of space I will refrain from repeating

\footnotetext{
${ }^{3}$ Rumelili, Bahar (2004): "Constructing identity and relating to difference: understanding the EU's mode of differentiation”, Review of International Studies, vol. 30, no. 1 (2004), pp. 27-47.
} 
these facts and arguments. ${ }^{4}$ For the purposes of this paper it suffices to note that in both cases, the roots of the disputes can be traced to the politics of early Cold War that drastically altered the US perceptions of its national interests and relations with its main WWII ally. Namely, increasingly complicated relations with the Soviet Union, the Korean War and other Cold War events, resulted in the various bodies of the US government (the main architect of the peace process with the defeated Japan) issuing a number of contradictory statements and decrees with the final draft of the Peace Treaty with Japan being rather brief and ambiguous. This ambiguity combined with multiplicity of documents and statements that preceded the signing of the Treaty enabled the parties to the disputes to produce interpretations supportive of their respective claims to the islands in question. ${ }^{5}$

The paper will proceed as follows. In its first part it will examine the various sub-state actors that participated in the Northern Territories and Takeshima related activism, their interests and actions. In particular, it will focus on the role of local governments (chihojichitai) and grassroots groups. The second part of the paper will examine the processes of incorporation of the territorial issues into national identity discourses, the domestic political changes that enabled this incorporation and the roles "Northern Territories" and "Takeshima" came to play in Japan's identity construction vis-à-vis Russia and South Korea respectively. In a nutshell, this paper argues that all of the actors have pursued their rational (maximization of material utilities) goals in their territorial disputes related activism. These goals, I argue had little to do with the "other", its differences or the national "self" construction but can be traced to other, more pragmatic interests of the actors.

\section{Grassroots Groups}

\subsection{Northern Territories}

The grassroots movement for the return of the Soviet occupied territory sprung on Hokkaido almost immediately after the completion of the Soviet occupation in September 1945. The numerous groups consisted of former residents of the occupied territories or residents of Hokkaido proper with vested interests in the territories.Reflecting the background of their members, some of the groups demanded the return of all of the Kuriles, others focused on the four islands known today as the 'Northern Territories', some only on Habomai and Shikotan, and some hoped for the return of southern Sakhalin as well. ${ }^{6}$ Besides the variety in the geographical scope of the territory, the various groups varied in terms of their interests related to the territory in question. Some were interested in the islands per se due to property rights. Other groups that included not only former residents but also fishermen from villages on Hokkaido or Northern Honshu had more interest in the fishing areas located in the waters

\footnotetext{
${ }^{4}$ For the Northern Territories/South Kuriles dispute see for example: Stephan, John (1975): The Kuril Islands: Russo-Japanese Frontier in the Pacific, Oxford, Oxford University Press; For the Takeshima/Dokdo dispute, see for example: Koo, Min Gyo (2009): Islands Disputes and Maritime Regime Building in East Asia, London, Springer, pp.63-102.

${ }^{5}$ Hara, Kimie (2006): Cold War Frontiers in the Asia Pacific: Divided Territories in the San-Francisco System, London, Routledge.

${ }^{6}$ Kuroiwa, Yukiko: "Dvijenie za vozvrashenie Severnyh territoriii Nemuro (The movement for the return of the Northern Territories and Nemuro)", Liberal Arts (Iwate Prefectural University), no.3 (2009), pp.1-20.
} 
adjacent to the islands. ${ }^{7}$ The analysis below will focus mainly on the movement formed the city of Nemuro which is considered to be the spiritual origin of the irredentist cause.

The first appeal to reverse the Soviet occupation appeared almost immediately after its completion in the town of Nemuro. Prior to the Soviet occupation, Nemuro was the center of the economic zone that encompassed the islands and the eastern part of Hokkaido. It was also the place where most of the former residents of the disputed islands have settled after the Soviet occupation. The movement was led by AndōIshisuke, the mayor of Nemuro. Andō and his followers formed an organization called the Commission to Petition for Returning Islands Attached to Hokkaido (Hokkaidō fuzokutōshofukkikonseiiinkai, hereafter the Commission). Most of initial members of the movement belonged either to the local administrative elite or held senior positions in the local fishing industry. All of them had clear personal stakes in the islands.Andō for example, owned a farm on Shikotan and was involved in running a crab cannery on Etorofu prior to the Soviet occupation. ${ }^{8}$. Later, however, probably as the result of the Soviet expulsions of the remaining residents from the islands, the movement expanded to include other members of the community.

Similarly to the grassroots organizations today, the Commission activities involved submission of petitions to the occupation authorities and the Japanese government and organization of rallies. Like other civil society organizations that emerged in Japan in the aftermath of the defeat, they campaigned against the policy pursued by the authorities, demanding its amendment. Thus it is not surprising that some of the activists were occasionally detained and questioned by the occupation authorities. ${ }^{9}$ As the main purpose of the irredentist activism was to improve the livelihoods of its members, the rationale behindtheir demands was dominantly economic. Broadly speaking, the ultimate purpose of the activism was reinstatement of the pre-1945local economic zone that included eastern Hokkaido and the southern part of the Kurile chain. This local economic zone having Nemuro as its center was interrupted by the Soviet occupation and the imposition of the so-called 'MacArthur line' that severely restricted the areas where Japanese fishermen could engage in fishing activities. Thus the early petitions submitted to the Occupation Authorities emphasized the economic importance of the waters adjacent to the Soviet occupied islands and urged the authorities to place them under the US occupation. ${ }^{10}$

Similarly to the later discourse on the Northern Territories, the petitions did champion the return of four islands and appealed to historical facts and international justice. The petitions also argued for a deep national (minzokuteki) connection of the islands to the city of Nemuro. In their attempt to attract attention they positioned the territorial issue within the broader question of postwar national revival. ${ }^{11}$ These arguments, however, were perceived as means in mobilizing governmental and public support for the irredentist cause and providing it with broad legitimacy rather than ends in themselves. As the main parts of the petitions as well as the internal debates of the Commission show, the return of the islands was seen as a

\footnotetext{
${ }^{7}$ Kajiura, Atsushi: "Rigai kōzō ni yoru hoppōryoudo henkan undō no bunseki" (Analysis of the irredentist movement for the return of Northern Territories from the perspective of interests structure), Kokusai kankeiron kenkyu, no. 7 (1989), pp. 97-127.

${ }^{8}$ Kushiro (1988): Andō Ishisuke to hoppōryōdo (Andō Ishisuke and the Northern Territories), Kushiro, Kushiro Shimbunsha.

${ }^{9}$ Ibid.

${ }^{10}$ Nemuro City (1997): Shima o kaese (Return the four islands!), Nemuro, Nemuro City Office.

${ }^{11}$ Ibid.
} 
matter of economic life or death for the city of Nemuro and hence carried a local and pragmatic agenda. ${ }^{12}$

To summarize the above, the irredentist movement in Nemuro was propelled by the severe aggravation of the local economy that resulted from the Soviet occupation of a significant part of the economic zone of eastern Hokkaido. The perceived value of the islands was dominantly economic and appeals to history and references to the nation in the early irredentist discourse were made based on strategic calculations in an attempt to draw a broad public and official support to their cause. Other groups formed by the former residents and local fishermen also pursued a pragmatic agenda that reflected their economic interests and the feasibility of their demands based on their interpretation of broader political issues that shaped Japan-USSR relations. In 1953, another significant grassroots group was formed in Nemuro. The group was called 'Nemuro Area Peace Preservation Economic Revival Alliance' (Nemurochihōheiwaijikeizaifukkōdōmei) and its members were mainly local fishermen and common residents. Headed by TOGASHI Mamoru who later became one of the local leaders of the left leaning civil movement protesting US war in Vietnam and Japan's complicity in it ${ }^{13}$, this Economic Revival Alliance championed the return of only two islands, perceived as the most pragmatic solution to the territorial dispute and subsequent alleviation of local fishermen livelihoods. ${ }^{14}$

\subsection{Takeshima}

The first organized citizen's group devoted to the Takeshima issue emerged only in 2004 and will be discussed in the final section of this article. However civil activism did exist on Shimane Prefecture's Oki Island, the administrative center of Takeshima, starting from early 1950s. Before proceeding further with analyzing the causes of this activism, it is important to briefly outline the international situation in the early 1950s in relation to Takeshima.

Takeshima islets or rocks were officially incorporated into Japan's Shimane Prefecture in 1905. The rocks cannot sustain human habitation and thus did not have any permanent residents but administratively they were part ofGoka village located on Oki Island. After Japan's defeat, the above-mentioned MacArthur Line imposed by the Occupation authorities precluded Japanese vessels from engaging in fishing activities in waters adjacent to Takeshima. In July 1952 due to its location and lack of permanent residents, Takeshima was designated by the US-Japan Joint Commission in charge of implementing the security arrangements as a special area used as bombing target practice area for US aircrafts engaged in the Korean War. Thus, while certain individual fishermen conducted trips to Takeshima, officially Japanese fishing and other vessels were prohibited from approaching the islets until March 1953. Six months prior to imposition of this restriction however, in January 1952, in the midst of Korean War and three months before the Peace Treaty with Japan came into force, South Korea's Syngman Rhee government issued a "Presidential Proclamation of Sovereignty over the Adjacent Seas" under which Korea declared national sovereignty over the seas within the designated line, known as the Peace Line or Rhee Line. The purpose of the line was to replace the Mac Arthur Line and establish Korean sovereignty over what the Rhee

\footnotetext{
${ }^{12}$ Ibid.

${ }^{13}$ Honda, Ryo'ichi (2006): "Nichiro kankei to anzen sōgyō (Japan-Russia relations and safe fishing)" in Iwashita, Akihiro and Honda, Ryo'ichi (eds.): Nichiro kankei no atarashi iapurochi wo motomete (In search for a new approach to Japan-Russia relations), Hokkaido University, Slavic Research Center, $21^{\text {st }}$ Century COE Occasional Papers no.25, pp.67-72, at http://133.50.171.227/coe21/publish/no15/contents.html.

14"Matsu'ura Yoshinobu testimony in front of Fisheries' Committee", House of Councilors (April 1 $\left.1^{\text {st }} 1954\right)$, National Diet Library database.
} 
government saw as Korean territorial waters. This move by the Korean government significantly increased the tensions in Japan's relations with its neighbor, led to heated diplomatic exchanges, seizures of Japanese fishing vessels and clashes between the Japanese and Korean fishermen.

However, already in summer 1951, well before the Peace Line Declaration, representatives of Oki fishing unions submitted two petitions, one to the Prefectural Assembly and another to the central government. Both of the petitions argued that resulting from the massive repatriation of soldiers and civilians to Japan's mainland from former colonies that followed Japan's defeat, Oki has experienced a sudden increase in overall population and inthe number of fishermen. ${ }^{15}$ This, the petitions argued, brought the urgent need to develop new fishing areas in order to be able to sustain the economy of the island that was completely dependent on maritime products. The petitions argued that the MacArthur Line restrictions aggravated the economic situation on the island and asked for the removal of restrictions on fishing activities in waters surroundingTakeshima. ${ }^{16}$ The conclusion of the San Francisco Treaty in September of the same year and the subsequent abolition of the MacArthur Line were met with high expectations by the local residents and manifested in a number of festive activities celebrating the expected resumption of "fishing on Takeshima". ${ }^{17}$

Thus at a first glance it may seem that the plight of Oki's fishermen was identical to that of the Nemuro area activists who sought to reestablish the local economic zone interrupted by Japan's defeat and the subsequent occupation. These parallels between the two movements can indeed be drawn, however with an important caveat. Namely, in the case of Takeshima, Oki fishermen's view of the islets as their rightful fishing zone was made possible by the occupation and the subsequent reforms. In other words, in a somewhat paradoxical fashion, the activism was spurred by the defeat and at the same time lobbied against its consequences. This paradox can be better understood if we briefly examine the economic activities on and around Takeshima during the pre-1945 years. In early $20^{\text {th }}$ century Takeshima was an important ground for seal hunting and to a lesser extent for abalone gathering. These two activities were monopolized by the Takeshima Fishing and Hunting Company established in 1905 and the successors of its three original owners. In 1908 the extent of Company's monopoly was extended to include fishing rights to adjacent waters. The Company employed Oki locals for seal hunting and Korean female divers for abalone gathering. In late 1920s, these exclusive rights were leased to a Japanese colonial entrepreneur based on Korean Ulleung Island who continued to monopolize the abalone gathering and fishing activities on and around Takeshima till Japan's defeat and his return to Japan proper. ${ }^{18}$ In 1953 , in line with the broad reforms initiated by the Occupation authorities, Shimane Prefecture abolished this monopoly and granted the rights to "fishing" (actually abalone, sea urchin and seaweed gathering and octopus catching) on Takeshima to Oki Fishing Union. Thus the celebrations of

\footnotetext{
15 The appeal to a sudden rise in population was not a mere rhetorical tool as statistical data from Shimane Prefecture shows that in 1947 the population of Oki was 42,400- 33\% more than the 31,794 residents in 1940. Shimane Prefecture (2011): "Shimane ken tōkeisho (Statistical data of Shimane Prefecture)", Matsue, Shimane Prefectural Statistics Association.

${ }^{16}$ Oki Fishing Union (1951): Takeshimagyoku no sōgyōseigen no kaijohōnitsukuchinjō (A petition to lift the operation restrictions in the Takeshima fishing zone).

${ }^{17}$ Sugihara, Takashi (2011): "San Francisco heiwa jōyaku teiketsu kinen Oki Gokamura no shokuju ni tsuite (Tree planning activities in Oki's Goka village celebrating the conclusion of San Francisco Peace Treaty)", Web Takeshima, at http://www.pref.shimane.lg.jp/soumu/web-takeshima/takeshima04/takeshima04-1/.

${ }^{18}$ Hayamizu, Takashi (1954):Takeshima gyogyō no hensen (Transitions in Takeshima fishing), Tokyo, Ministry of Foreign Affairs, Asia Bureau, Second Section.
} 
the Peace Treaty on Oki and the petitions were spurred by the memory of the colonial economic subzone that included Oki, Takeshima and Ulleung Island and where members of Shimane elite controlled the economic activities. At the same time however, Oki fishermen activism was triggered also by the reforms initiated by the Occupation Authorities that enabled Oki fishermen to perceive Takeshima as their collective fishing grounds.

Oki fishing unions and the municipal authorities continued their petitioning activities in the 1950s and 1960s. Overall the arguments and the perceptions of the territorial dispute were similar to those espoused by the prefectural authorities.

\section{Regional Governments}

\subsection{Hokkaido Prefecture and the Northern Territories}

From 1950 onwards the Hokkaido prefectural government under the leadership of the Socialist Governor Tanaka Toshifumi fully embraced the irredentist cause. Hokkaido Prefectural government under the leadership of Tanaka played an important role in establishing another major non-governmental organization called the Alliance for Petitioning the Return of the Chishima and the Habomai islands (Chishima oyobi Habomai henkan konsei domei) (hereafter the Alliance). In an attempt to establish it as representing Hokkaido as a whole, the board of directors included the mayors of all of the main cities and towns in the prefecture. Its funding was coming mainly from the prefectural government. The active involvement of prefectural government in the irredentist cause and the formation of the Alliance which was dependent on the prefecture for funding signified the beginning of a process of a gradual appropriation of the irredentist cause and its institutionalization on the prefectural level.

The main explicit reason that drove Tanaka's administration to engage in the territorial issue was the fear that despite the heavy investment of resources into the development of the Kurilessince the $19^{\text {th }}$ century, the central government may give up the Soviet occupied territories during the peace settlement. ${ }^{19}$ Tanaka's prior carrier as a public servant at the Department of Forest Management of the Hokkaido Prefecture as well as his vision for an overall development of Hokkaido also probably played an important role in arousing his interest in the islands that included the timber rich Kunashiri. At the same time however, it is important to remember that in 1950, the year prefectural government embarked on its active participation in the irredentist movement, Tanaka's administration engaged in a fierce conflict with the central government over the establishment of the Hokkaido Development Agency within the Cabinet Office. The rationale behind the creation of this administrative body, whose responsibilities overlap with those of the prefectural administration, was generally understood as a conservative attempt to wrestle the control over Hokkaido from the influence of the Socialists and fiercely contested by Tanaka. ${ }^{20}$ Thus, the irredentist cause provided another platform for Tanaka to criticize the central government and to enhance his own legitimacy in the eyes of Hokkaido residents. In line with the general focus on economic development espoused by Tanaka, his rationale for championing the return of the islands was similar to that of the grassroots organizations. Namely, the islands were argued to be the main

\footnotetext{
${ }^{19}$ Tanaka, Toshifumi (1950): Chishima henkan konsei ni kan suru shoken (Opinion regarding the appeal for the return of Chishima), Hokkaido Prefectural Library, Hokkaido Prefectural Government..

${ }^{20}$ Hanno, Akihito (2003): Hokkaido kaihatsukyoku to wananika (What was the Hokkaido Regional Development Bureau), Sapporo, Juyrosha.
} 
source of protein for Japan and constituting an integral part of Hokkaido economic zone. ${ }^{21}$ Contrastingly to the grassroots organizations that pursued an improvement of their livelihoods, the struggle with the central government played an important role in shaping prefectural and its affiliate, the Alliance for Petitioning the Return of the Chishima and the Habomai islands agenda. Thus, in opposition to PM Yoshida's government which, however reluctantly, renounced Japan's rights to the Kuriles at San-Francisco Peace Conference, Tanaka and the Alliance followed the position of Japan's Socialist Party and advocated the return of all of the Kurile chain as well as the Shikotan and the Habomais.

Thus, in early 1950s the Hokkaido prefectural government went against the conservative government's policy and advocated the return of all of the Kuriles, Habomais and the Shikotan. Tanaka admitted the renouncement of Japan's rights to all of the Kuriles in the Peace Treaty and at the same time argued that this action did not reflect the wish of the people of Japan. ${ }^{22}$ By following this line of argument the Alliance and Tanaka's administration engaged in implicit critique of Yoshida's government for its lack of adherence to the democratic principles. Just like the conservative government brought the struggle with the left to Hokkaido by establishing the Development Agency, Tanaka and his affiliates utilized the territorial dispute in their attempt to bring their struggle with the central government to Tokyo. Thus for example, a mass rally sponsored by the Hokkaido Governor, Hokkaido Assembly and the Alliance was held in Tokyo on $19^{\text {th }}$ of July, 1953. The declaration issued by the rally contested the secession of the Kuriles in San-Francisco. Appealing to the 'instinctive desire' shared by all humans to protect a territory which was developed by shedding 'sweat and blood', it called for the correction of this injustice and demanded the return of all of the Kurlies as well as the Habomais and Shikotan. ${ }^{23}$ Bearing in mind the importance of the broader rivalry with the conservatives dominated center, it can be argued that despite the nationalistic rhetoric, the symbolic value of the islands for Tanaka's Hokkaido administration was mainly in their delegitimizing effect on Yoshida led central government.

During the 1955-56 peace treaty negotiations between Japan and the Soviet Union, many on Hokkaido believed that they will result in a return of at least parts of the occupied territories. In February 1956, taking advantage of this widely spread belief the prefectural administration established a new department named Headquarters for Countermeasures Related to Reversion of Territory and Fisheries within its General Affairs Division. The official purpose of this department was to collect data and to plan the reconstruction and development of the territories that will be returned by the Soviets but also to engage in "nurturing" and "guiding" related grassroots organizations. ${ }^{24}$ Thus this further institutionalization of the territorial cause on the prefectural level can be seen as an attempt to capitalize on the possible return of the two islands and to consolidate the local public opinion under the banner of "return of all of the Kuriles". Three years later, however, Socialist candidate lost the gubernatorial elections and a former LDP Diet member MachimuraKingo, became the new Governor of Hokkaido. This meant that from now onwards, the prefectural policy on the territories will be in line with that of the state and that the various institutions established under Tanaka will now serve the policy of the central government.

\footnotetext{
${ }^{21}$ Tanaka, op. cit.

${ }^{22}$ Kuwabara, Teruji (1965): The History of the Movements for the Return of the Northern Territories, Sapporo, The Association for the Return of the Northern Territories.

${ }^{23}$ (1953): Chishima oyobi Habomai shotō henkan konsei kokumintaikai, Hokkaido, Hokkaido Prefectural Library.

24 "History of the Northern Territories", Hokkaido Prefecture Website, at http://www.pref.hokkaido.lg.jp/sm/hrt/hp/histo.htm.
} 
This policy of creating a national mission out of Northern Territories related irredentism pursued by the LDP led government can be seen as fully rational within the domestic political context of the 1970s and 1980s. The end of the Cold War and the changes in domestic politics that took place in the 1990s, however, stripped this policy of its initial rationality. The idea of the "Northern Territories" however took a life of its own and proved to be invisible against attempts to question its rationality in the context of radically different international and domestic environments.

\subsection{Shimane Prefecture and Takeshima}

Shimane Prefecture's Takeshima related activism started in early 1950s and was spurred by petitions that emerged from Oki. On the $10^{\text {th }}$ of March, 1953 a week prior to lifting of the "special area" measures that restricted Japanese access to Takeshima Shimane Prefectural Assembly adopted a resolution on the issue. The unanimously adopted resolution argued that the islets are an integral part of Oki Island's Goka village administrative area and are in need of further development under the forthcoming Remote Islands Development Law. It called the central government to recognize the importance of Takeshima as a fishing area and to take all possible measures to protect it. ${ }^{25}$

There is little doubt that the prefectural authorities sincerely believed that Takeshima belongs to Japan and the ownership of the rocks had little to do with Japan's colonial rule over Korea. Furthermore, Korean seizures of Japanese fishing vessels and detainments of fishermen prompted the prefectural authorities to engage the issue and appeal to the state to take measures. At the same time, to a certain extent the importance attached to the rocks by the prefectural authorities is directly related to Japan's colonial legacy. Namely, as the result of the defeat and the loss of colonies Japanese fishermen lost access to fishing grounds in waters adjacent to the Korean Peninsula. Along with the already mentioned sudden increase in population, and natural calamities in preceding years ${ }^{26}$ this was one of the factors behind Shimane Prefecture's sense of urgency to establish its rights to Takeshima and develop new fishing grounds in adjacent waters. ${ }^{27}$ Thus, regardless of the question of legality of Japan's claims to the rocks, the initial attention paid to the issue by the prefecture stemmed directly from Japan's colonial history.

From early 1950s onwards, Shimane Prefecture continuously lobbied the government to establish territorial rights over Takeshima and to enable safe fishing conditions. During the final round of normalization negotiations between Japan and Korea in early 1960s, Shimane Prefectural authorities vehemently opposed the idea of joint ownership over Takeshima floated by one of LDP heavyweights. ${ }^{28}$ In the same year local activists proposed to establish an Alliance for Securing the Territorial Rights to Takeshima (takeshima ryōdo ken kakuho kisei domei). The purpose of the organization which according to the proposal was to be headed by the governor of Shimane Prefecture and whose executive body would have been comprised of high level prefectural politicians and head of the prefectural fishing union was to act as an advocacy agent aimed at mobilizing residents of Shimane but also the broad

\footnotetext{
${ }^{25}$ Shimane Prefectural Assembly (1958): Records of 147th Shimane Prefectural Assembly Meeting, Matsue, Shimane Prefectural Assembly, pp.81-82

${ }^{26}$ Tamura, Kyosaburo (1955): Takeshimamondai no kenkyū(Study of Takeshima Problem), Matsue, Shimane Prefecture, General Affairs Division, p.65.

${ }^{27}$ Shimane Prefecture (1965): Takeshima no gaiyō (Outline of Takeshima), Matsue, Shimane Prefecture.

28 "Takeshima, nikkankyō yūan mo aru" (Takeshima: there is also a proposal for joing ownership), Asahi Shimbun, 10 January 1963, Tokyo, morning edition, p.1.
} 
public in Japan and exercise direct and indirect pressure on the government "not to abandon" territorial rights to Takeshima in the process of negotiating with Korea. ${ }^{29}$

After the conclusion of the Japan-Korea Treaty on Basic Relations which normalized the relations between the two countries and shelved the territorial dispute, Shimane prefectural authorities continued their petitioning activities. In 1977 after over a decade of relative calm, the tensions around the territorial dispute have heightened again. Following the US and Soviet declarations of 200 miles exclusive fishery zones Japan and Korea declared 12 miles territorial waters and 200 miles exclusive fishery zones. In this context the question of territorial rights to Takeshima surfaced again in the domestic debates in both counties and resulted in a number of heated exchanges.

During this period, Shimane Prefecture made a number of attempts to revive the Takeshima issue and apply pressure on the government to bring it back to negotiations table with Korea. In February 1977, the Prefectural Assembly passed a resolution calling for "maintenance of territorial integrity and securing safe fishing." Two years later, in April 1979, after over a quarter of a century of petitioning the central government to resolve the Takeshima issue, Shimane Prefecture established an organization called Shimane Prefectural Council for Facilitating the Solution of Takeshima Problem. It purpose was to coordinate Takeshima related activities of the various bodies involved such as the prefecture, municipal authorities and fishing unions, and to engage in petitioning and enlightenment activities. This was the starting point for enlightenment activities conducted by the prefecture. These activities that included publication of pamphlets and construction of road signs that called for the return of Takeshima, were directed at the prefectural residents with the purpose of raising residents' awareness and deepening their understanding of the Takeshima problem. ${ }^{30}$

What accounts for this escalation in prefectural government's activities and how can their nature (enlightenment of Shimane's residents) be explained? One could argue that the damage suffered by Shimane's fishermen as a result of Korean policy of excluding them from the radius of 12 miles zone around Takeshima enhanced the sense of urgency among the prefectural authorities. In June 1978, the prefecture published a report that estimated the losses from the exclusion of Japanese fishermen from waters around Takeshima at three hundred and twenty million yen. ${ }^{31}$

Statistical data however shows that during the late 1970s the actual catch did not decrease and for some kinds of fish and squid it actually increased in 1979 and $1980 .{ }^{32}$ It could be argued that regardless of the actual damage to Shimane's fishing industry, simply a perception of damage drove the prefectural government towards intensification of its Takeshima related activities. To a certain extent, the perception of damage probably did play a certain role. This however does not explain the nature of the activities initiated by the prefectural authorities. In other words, one could expect enhanced demands from the central

\footnotetext{
${ }^{29}$ Shimane Prefectural Assembly (1965): Takeshima no ryōdoken kakuho ni kan suru kenminundō suishin yōkōan (An Outline of Proposal to Promote Prefectural Citizen's Movement for Securing Territorial Rights to Takeshima), Matsue, Shimane Prefectural Assembly.

${ }^{30}$ Shimane Prefecture (1983): Kensei no ayumishowa 54-57 (Prefectural Politics 1979-1982), Matsue, Shimane Prefecture, General Affairs Division.

${ }^{31}$ Cited in Fukuhara, Yuji: "Gyogyōmondai to ryōdomondai no kōsaku (The interplay of fishing and territorial disputes)", Shimane Journal of Northeast Asian Research, no. 23 (2012), pp. 65-78.

${ }^{32}$ Chugoku Regional Agricultural Administration Office (1984): Shimane ken gyogyo no ugoki (Changes in Shimane Prefecture's fishing industry), Matsue, Agricultural Administration Office.
} 
government but what is the rationale for enlightening the citizens of the prefecture about the Takeshima issue? A different light can be shed on this issue if we examine the nature of Shimane Prefectural authorities' relations with the central government in late 1970s.

In 1972, Tanaka Kakuei published his famous "Remodeling of Japan's Archipelago" plan which became the backbone of governmental policy under his leadership and envisioned industrialization and economic alleviation of underdeveloped areas of Japan through improved infrastructure and connectivity. Shimane was one of these areas but the benefits it gained from the new plan were rather modest. For example, the plan for Sanin Shinkansen line that was supposed to connect Shimane's Matsue and other prefectures in the San'in area with Osaka

The plan however was put on hold and did not materialize until the present day. Thus in can argued that the territorial dispute was seen as an important channel to express prefectural discontent with the overall disparity in the execution of the "remodeling" plan and continuous economic disparity between Shimane and other regions, and simultaneously to draw central government's attention to the economic plight of the prefecture. Furthermore, it is important to remember that from 1975 till 1987, the governor of Shimane Prefecture was Tsunematsu Seiji, a former economist and one of the most forceful advocates of domestic decentralization, arguing that regional governments should be given more independence that should eventually lead to establishing a federal system in Japan. Thus during Tsunematsu's governance, Shimane was an integral part of "progressive municipalities" (kakushinjichitai) who opposed the LDP led central government of a wide range of domestic issues. In this context, intensification in prefectural activism related to Takeshima can be seen as an integral part of Tsunematsu led Shimane in legitimizing the claims about the ineffectiveness of central government and provide further support for federalism as an ideal political structure for Japan.

Between mid 1980s and mid 1990s, Shimane Prefecture continued to submit its annual petitions to the central government but otherwise the scope of prefectural activities related to Takeshima was rather limited. The territorial dispute flared up again in mid 1990s, when both Korea and Japan ratified the United Nation's Convention of the Law of the Seas (UNCLOS) and engaged in prolonged and difficult negotiations aimed at amending the fishing treaty without resolving the territorial dispute. In 2004, Shimane Prefecture passed a prefectural ordinance that designated the $22^{\text {nd }}$ of February, the day Takeshima was officially incorporated into Shimane Prefecture in 1905, as the prefectural Takeshima Day. The fierce reaction from Korean authorities and public as well as the subsequent use of the Takeshima issue by domestic politicians swiftly elevated "Takeshima" from virtual oblivion to one of the most important issues in Japan's identity discourse on the Korean "other". Thus for example a search on one of Japan's magazine articles searching engines Ōya Bunko gives only 65 hits for a search with "Takeshima" and "problem" keywords for the years 1951-2003 and 539 hits for a similar search conducted for the years 2004-2012. This intense media attention played an important role in public's interest of the issues. For example, in a poll conducted by Yomiuri Shimbun in 2006, 59\% of the respondents said that they are interested in the dispute-this while four years earlier only $13 \%$ believed that Takeshima is an important problem in bilateral relations. ${ }^{33}$ There is little doubt that intensification in Japan's other territorial disputes and most notably the one with China over the Senkaku/Diyaoyu islands played an

\footnotetext{
${ }^{33}$ Cited in: Nakajima, Kentaro: Is Japan Maritime Strategy Changing? An Analysis of the Takeshima/Dokdo Issue, USJP Occasional Paper 07-08 (2007), at http://www.wcfia.harvard.edu/us-japan/research/pdf/0708.Nakajima.pdf, p.23.
} 
important role in drawing public attention to the Takeshima dispute. At the same time the role of Shimane Prefecture's "Takeshima Day" ordinance should not forgotten. Thus while not ignoring other factors, we can plausibly argue that after over half-century of activism Shimane Prefecture managed to elevate "Takeshima" from obscurity to the fore of public discourse on the Korean "other". Mechanisms that enabled this move will be discussed in the following section.

\section{Nationalization of Territorial Disputes}

\subsection{Northern Territories}

Both the grassroots organizations and Hokkaido Prefectural government failed in their attempts to spark a nationwide interest in the "Northern Territories" issue and draw attention to the plight of former residents and others affected by the dispute. In mid 1960s, even on Hokkaido the interest in the territorial dispute was minimal. A public opinion poll conducted on Hokkaido in 1966 shows that around 40\% of the respondents did not know the geographical scope of "Northern Territories", more than half of the respondents did not know the historical justification for Japan's claims to the islands and less than $10 \%$ chose the "Northern Territories" as an issue of interest among other international issues directly or indirectly related to Japan. ${ }^{34}$

"Nationalization" or the incorporation of the Northern Territories dispute into national identity discourse was achieved through intentional efforts of the LDP led government. It must be noted that the government did not completely ignore the plight of the former residents and fishermen and did take a number of measures aimed at addressing their material needs in the 1950s and early 1960s. Government's interest in the dispute and in particular its domestic aspects increased dramatically in late 1960s. In 1969, Association for Countermeasures related to the Northern Territories (hoppō ryōdo mondai taisaku kyōkai, hereafter the Association), a new quasi-governmental agency in charge of the domestic activities related to the 'Northern Territories' was established. One of the main activities of this organization has been to enhance and spread the knowledge of the territorial issue (meaning Japan's official interpretations of the history of the dispute and various documents that justify its claims) among the Japanese people.

There is no definite answer regarding the rationale that drove the LDP led government towards embracement of the irredentist cause. It seems though that political calculations related to domestic politics played an important role. The reason, it has been argued, was directly related to the Japan-US negotiations regarding the reversion of Okinawa. Namely, through enlightenment activities, the ruling LDP was hoping to sway the public support away from the Socialist Party which opposed the reversion of Okinawa with American bases. ${ }^{35}$ Thus, the territorial dispute gained further importance in the LDP's rivalry with its opponents. The symbolic meaning of the "Northern Territories" resided mainly in their association with the Soviet Union and by default with the domestic progressive forces that included the socialists and the communists. In pursuing its goal of consolidating the nation, the government embraced the terminology and the techniques deployed by the grassroots

\footnotetext{
${ }^{34}$ Hoppō ryōdo fukki kisei dōmei (1966): "Hoppō ryōdo mondai ni kan suru seiron chōsa (Public opinion survey on the Northern Territories)", Sapporo, Hoppō ryōdo fukki kisei dōmei.

35 Ikeda, Naotaka: "Showa 45 nendai no hoppō ryōdo mondai (The problem of the Northern Territories in the 1970s)", Gunjishigaku, vol. 39, no. 3 (2003), pp.39-53; p.42.
} 
organizations. Government sponsored publications on the issue adopted such strongly nationalistic terms as 'our inherent territory' and 'land inherited from our ancestors' initially introduced by the Hokkaido based movement. Furthermore, the enlightenment strategies such as distributing pamphlets, organizing 'people's rallies' and public events became an integral part of the government led campaign. The drive to 'enlighten' the public quickly spread in the society. Newspapers, magazines and even department stores quickly became mouthpieces of the irredentist cause. ${ }^{36}$

Along with the process of nationalization of the irredentist cause the domestic discourse on the lost territories and related events gradually became homogenized. In a somewhat ironic fashion, the institutionalization of the irredentist cause on Hokkaido initiated by the Governor Tanaka in the early 1950s as a tool of struggle with the central government came to serve the interests of his foes after the conservative victory in the 1959 gubernatorial elections. . Along with the general demise in public activism in Japan, the abovementioned 'Nemuro Area Peace Preservation Economic Revival Alliance' which belonged to the progressive grassroots activism and received no support from the government, faded into oblivion. Those organizations that survived till the present day are fully dependent on governmental assistance. The institutionalization of the irredentist cause on the grassroots and Hokkaido prefectural levels contributes to the continuous reproduction of the illusion of a synergetic relationship among the central government, the prefectural administration and the people. This creates a certain illusion of the governmental position on the islands as being dependent on public opinion or of a certain interest group. However, today the noncompromising stance can hardly be traced to any particular interests.

\subsection{Takeshima}

The process of nationalization of Takeshima dispute is strikingly different from the one described above. While nationalization of Northern Territories can be attributed to the efforts of LDP pursuing their domestic political goals, the emergence of Takeshima as one of the central points of reference in Japan's discourse on the (South) Korean "other" can be traced to the collapse of LDP's internal control mechanisms. Before proceeding further however it is important to outline LDP's long standing position on the territorial dispute with South Korea.

In early 1950s, Japanese government vehemently protested Korean de facto occupation of Takeshima and the territorial dispute was one of the main stumbling stones in bilateral normalization negotiations. The situation however changed after the 1961 coup de etat that brought Park Chung Hee to power. Park viewed Japan's financial assistance as vital to Korean development and he embarked of developing closer ties with Japan soon after seizing power. On the Japanese side, the rapprochement was driven by the so-called "Korean lobby"-loose association of business executives and strongly anti-communist conservative politicians that formed around KISHINobusuke. ${ }^{37}$

The negotiations eventually led to the conclusion of the Japan-Korea Treaty on Basic Relations that normalized the relations between the two neighbors and a fishing agreement that enabled the two governments to shelve the territorial dispute. According to Daniel Roh, the two governments reached a secret pact according to which status quo will be maintained

\footnotetext{
${ }^{36}$ Stephan, op. cit.

${ }^{37}$ Roh, Daniel (2008 ): Takeshima mitsuyaku (The Takeshima Secret Pact), Tokyo, Soshisha.
} 
and domestically both sides will continue to make claims of sovereignty but will not contest the other side's claims internationally. ${ }^{38}$

Roh does not provide any hard evidence in his book but Japan/LDP policy related to the dispute indirectly supports his argument. Throughout the years, references to the dispute in governmental and party publications were kept to a minimum or were simply omitted. ${ }^{39}$ In the Diet interpolations in 1964 and 1965 that preceded the conclusion of the Basic Relations Treaty none of the LDP MPs, including those elected by Shimane constituency, raised the Takeshima question. With only a limited number of exceptions, this policy of keeping theTakeshima issue on the back burner of domestic politicswas maintained by the LDP throughout its years in power. This continued regardless of the changes in power relations among various fractions the LDP.

What enabled then Shimane Prefectural Assembly dominated by LDP members to pass an ordinance that went against the will of LDP heavyweights like AOKI Mikio? The idea itself of inspired by the "Northern Territories Day" 0 but the political mechanisms that enabled the passage of the ordinance can be attributed to the collapse of LDP's internal power relations that resulted from PM Koizumi's reforms.

In 1972 SATO (Eisaku) fraction came under the leadership of Tanaka Kakuei and became the strongest fraction within the LDP. In 1987 it was renamed Takeshita (Noboru) fraction (or Keiseikai) and continued to play central role in the party governance. Takeshita was a native of and elected from Shimane. Ironically, however, as a faithful student of SATO Eisaku under whose premiership Japan's relations with Korea where normalized, and a onetime Chairman of Japan-Korea MPs Alliance he was also one of the heavyweights in the socalled "Korean lobby", which attributed more importance to maintaining good relations with Korea over demanding the return of Takeshima. Takeshita's reluctance to engage in the territorial dispute and to follow the arrangements of the "secret pact" discussed above can be seen in his attitude to the dispute in the Diet. During the four decades of his political carrier he referred to the dispute only twice and very briefly during the parliamentary interpolationsonce as the Minister of Finance during discussions of the fishing issues between Japan and USSR in 1987 and once during his questioning over the Sagawa Kyubin bribing incident in 1992. ${ }^{41}$ Takeshita fraction split into two (Ozawa group and Obuchi group) in 1992 as the result of growing in-fraction dissatisfaction with Ozawa Ichiro who by that time became the most powerful figure in the Keiseikai. The importance of the fractions in general further demised after the 1994 elections system reform. ${ }^{42}$ Nevertheless, Keseikai bosses continued to play central role in the LDP after the split and the elections reform throughout the 1990s: for example, all of the Prime-Ministers (expect for the brief period of the socialist Murayama) were from the former Takeshita fraction. There is no direct evidence that Keisekai leaders directly obstructed Takeshima related initiatives of the Shimane prefectural assembly members prior to 2004. At the same time it can be argued that the emphasis on solidarity and strict top-down relations that characterized Keiseikai ${ }^{43}$ as well as the importance of the party in

\footnotetext{
${ }^{38}$ Ibid.

${ }^{39}$ For example, see: Nan pōdō hōen gokai (1965): Nihon ryōdo no hanashi (A talk on Japan's territory), Tokyo, Nan pōdō hōen gokai.

${ }^{40}$ Nagai, Yoshihito: "The Process of Establishing Takeshima Day in Shimane Prefecture" (in Japanese), Hiroshima Journal of International Studies, no. 18 (2012), pp.1-18.

${ }^{41}$ Search conducted on the $20^{\text {th }}$ of March 2013 at National Diet Library search engine, at http://kokkai.ndl.go.jp/.

${ }^{42}$ Kitaoka, Shin'ichi (1995): Jimintō (LDP), Tokyo, Yomiuri Shimbunsha.

${ }^{43}$ Ferkov, Anton: "Jimintō saikyō habatsu 'Tanaka ha/Keiseikai' no bunseki (Analysis of LDP's strongest faction

"Tanaka faction/Keiseikai")", Kōdōkagakukenkȳu, vol. 49 (1997), pp. 63-78.
} 
mobilizing funding for politicians made an emergence of any local level initiative that went against its policy structurally impossible. The rise of Koizumi Junichiro to chairmanship of the LDP and subsequently to premiership in 2001 however dealt an invincible blow to the internal governance of LDP still dominated by the successors of Keiseikai. Besides coming from a rival faction (Seiwakai/Fukuda faction), Koizumi saw it as his mission to destroy the LDP which for him was synonymous with the dominance ofKeiseikai. The concentration of policy-making in the Prime-Minister's Office (as opposed to the previous center of gravity that rested with the faction's leaders) and the split of the old LDP during the debates over privatization of the postal service that culminated in the "postal elections" of 2005 had probably its merits for Japan's politics but from the perspective of intra-party governance it eroded if not completely destroyed the existing mechanisms. Arguably this collapse of the intra-party governance can be seen as the key factor that enabled a group of Shimane prefectural lawmakers dominated by LDP members to pass an ordinance that went again the existing party policy and despite strong suggestions not to enact it that were given by a number of powerful party members.

The passage of the ordinance was mainly an act of rebellion against the central government and thus its broad implications were not anticipated by the prefectural assembly members that initiated the move. ${ }^{44}$ The Korean side fiercely reacted to the ordinance, perceiving it as having central government backing. The exchange of rhetoric that followed, the symbolic gestures such as lifting the ban on domestic tourism to the islets by the Korean authorities and symbolic retaliations, the possibility of clash between the two countries' navies after Japan's decision to send survey ships in 2006 as well as the political usage of the Takeshima issue by Japanese and Korean politicians, attracted intense attention from the media and placed the territorial dispute in the center of Japan's debates on Korea. Thus, unintentionally Shimane prefectural authorities created an important symbolic milestone in Japan's national identity construction vis-à-vis the Korean "other".

"Nationalization" of Takeshima was further enhanced by a newly established citizen's group, called "Group to Protect Prefectural Territory-Takeshima" (kendo takeshima o mamorukai). The Matsue (Shimane's administrative center) was established in May 2004, in the midst of exchanges between the Prefecture and the central government regarding the enactment of "Takeshima Day". The core of the group is comprised of local activists that initially became acquainted when collecting signatures for petitions related to people abducted by North Korea and it is headed by one of the local Shinto priests. The group is the first and only grassroots organization dedicated to Takeshima issue. ${ }^{45}$ Since the escalation in Takeshima related activities and the spread in the domestic interest in the issue, this group which according to their own estimates has about 1000 supporters nationwide, has played an important role in organizing related events and attracting local but also national level politicians to participate in these events. ${ }^{46}$ Initially largely unnoted, over the years the activities of the Groupcame to be covered by major newspapers and thus its existence became quite important in creating the semblance of a widespread citizens' interest in the Takeshima issue.

\footnotetext{
${ }_{45}^{44}$ Nakai, op. cit.

${ }^{45}$ For the purposes of this paper, I exclude the ultra right-wing organizations (uyoku) that have continuously used all of the issues (including territorial disputes) that exist between Japan and its neighbors when advocating their militant agenda.

${ }^{46}$ Interview with Kajitani Mariko, Secretary General of "Group to Protect Prefectural Territory-Takeshima" conducted on the $16^{\text {th }}$ of December, 2012, Matsue, Shimane Prefecture.
} 


\section{Conclusion}

This paper has examined the domestic processes that transformed the territorial disputes over Northern Territories and Takeshima into important issues in Japan's national identity construction vis-à-vis USSR/Russia and South Korea respectively. It showed that while the final results are quite similar, the processes that enabled this transformation have been fundamentally different. In the case of the Northern Territories, the "nationalization" of the dispute took place as part of an intentional policy of the LDP aimed at diverting Japanese national sentiments away from the US and its continuous military dominance on Okinawa towards the Soviet Union. In the process however, the LDP led government adopted the strategies originally developed by the grassroots organizations and Hokkaido prefectural authorities. Furthermore, the existence of these organizations and their selective nurturing enabled the prevalence of the semblance of a national mission with both the government and the people working towards achieving one goal. Contrastingly, in the case of Takeshima, I argued that the "nationalization" of the dispute occurred against the intentions of the LDP and can be attributed to the collapse in its internal governance that resulted from Koizumi's reforms.

In this paper I also argued that the interests pursued by the various actors can be classified as rational and had little to do with contributing to national identity discourse. As Michel Foucault, has noted“...every sentiment, particularly the noblest and the most disinterested, has a history". ${ }^{47}$ This history can be traced to very pragmatic and immediate interests of the actors and it's the winding roads of history with its unexpected shifts in relations of power that enable the transformation of certain pragmatic interests into sentimental identity constructs.

\footnotetext{
${ }^{47}$ Foucault, Michel (1991): "Nietzsche, Genealogy, History" in Rabinow, Paul (ed.): The Foucault Reader, London, Penguin, pp.76-100; p.78.
} 